\title{
Particularidades sobre papers
}

Hoje em dia a produção científica pretende ser mensurada pelo número de artigos - os famosos papers (não quer dizer papel, assim como Journal não significa jornal, pois indica revista científica) e se um cientista nacional consegue publicar a sua pesquisa numa revista estrangeira, indexada (o que significa que o trabalho vai para uma grande base de dados onde todos pesquisadores do mundo podem ter acesso a pelo menos um resumo dela) é a glória. E isto é difícil: autores de países subdesenvolvidos nem sempre são bem vistos pelos editores das revistas médicas de maior reputação; os artigos que têm que ser escritos em inglês, a língua internacional da ciência, e muitos de nossos pesquisadores massacram sem piedade a gramática e até a ortografia inglesa, de idioma reconhecidamente mais complicado para escrever bem que o nosso.

Um ponto importante éque a ciênciaé a procura do conhecimento, não é maratona ou competição atlética. Artigos muito importantes e originais já foram rejeitados por editores - e o jeito mais fácil de conseguir ser publicado é fazer uma pesquisa de resultados bem previsíveis, dentro do que Gallbraith chama de sabedoria convencional - ou seja, algo muito parecido com o que já for feito e cujo valor, se algum, é apenas corroborar o que todo mundo já sabe. Pior que isto, matérias originais e de valor provenientes de fontes menos conhecidas já foram barrados enquanto os revisores em países desenvolvidos, aproveitaram as circunstâncias fazendo publicações rápidas mediante uso de tais informações - e ficando com a prioridade. Diga-se a bem verdade que estas coisas não ocorrem só com revistas estrangeiras, como também não é verdade que o que é publicado em revistas brasileiras não tem valor. Temos de tudo. Hoje muitas das nossa revistas como os Cadernos de Saúde Pública, a Clinics, as Memórias do Instituto Oswaldo Cruz, a Revista do Instituto de Medicina Tropical de São Paulo, a Revista de Saúde Pública, a Revista da Sociedade Brasileira de Medicina Tropical e o São Paulo Medical Journal são em geral indexadas no Index Medicus, a tal base universal de dados. São outrossim escritas em inglês e isto é cabível aceitar. Contam com criteriosos, competentes e respeitáveis Conselhos Editoriais e, convenhamos, afiguram-se prestimosas ao cooperar com o atendimento médico, sob diversos aspectos, colaborando expressivamente com a saúde pública.

Em colaboração recentemente apresentada nos Cadernos de Saúde Pública, Castiel LD e Sanz-Valero J, um pesquisador da Fundação Instituto Oswaldo Cruz e, o outro, da Universidade de Alicante, Espanha, discutem qual o motivo fundamental da preocupação nos âmbitos acadêmicos com a produtividade científica, expressa em publicações - incluindo detalhes. Uma divulgação em revista de maior índice de impacto (sim, existem estas classificações de importância das revistas) possui maior valor que outra e, depois, o número de citações dos textos, que também tem uma aferição numérica, o famoso citation index, igualmente é valorado, para julgar, promover ou descontratar pesquisadores. Segundo estes autores há um fetichismo, onde o paper é visto como mercadoria a ser vendida e o investigador como um especialista em marketing da sua produção. E isto de fato existe - como existem especialistas em aumentar a produtividade dos seus escritos com a técnica salsicha, fatiando o trabalho no que eles chamam jocosamente de MPP (minimum publication piece), para que um único estudo renda pelo menos umas sete difusões em várias revistas, aumentando assim o capital do(s) pesquisador(ores).

Precisamos perguntar-nos se critérios de contratação de professores universitários devem basear-se quase que exclusivamente nesta visão de produtividade. Um dado que parece freqüentemente ser esquecido é que professor universitário na área médica obrigase a desempenhar compromissos cruciais. Ele inicialmente precisa ensinar-é para isto que foi contratado, não é? Portanto deve ter algum grau de didática, vontade de ensinar e dispor de tempo reservado para este mister, que às vezes é considerado menos nobre. Não é. Como não é menos importante ou menos nobre ensinar na graduação, diante de opiniões que destacam a pós-graduação. Por este tipo de visão cada vez mais aprende-se menos na graduação - e nem todo mundo tem interesse, vontade, tempo e condições financeiras envolver-se em curso de pós-graduação. Ele deve atuar na assistência a pacientes ou participar a fim de que seu serviço seja útil à comunidade a que serve. E deve sim fazer pesquisa - mas não só. E sua pesquisa pode lograr enorme valor, com poucas publicações. Einstein, que era Einstein, no seu ano mágico, apresentou quatro relatos que foram fundamentais para a Física - e são estes pelos quais ele é o que sabemos que foi. Depois publicou alguma coisa, mas bem pouco - talvez hoje ele fosse considerado modestamente produtivo pelos burocratas acadêmicos.

Voltando à área médica, existem cientistas de valor que publicam poucos trabalhos, mas de muito peso, e temos alguns que publicam muito, inclusive em revistas estrangeiras, sem tanto valor. Não negamos que seja necessário publicar: pesquisa não conhecida não se incorpora à soma de conhecimentos que levam a humanidade para a frente. Mas também não é adequado o publish or perish dos norte-americanos, que gera efeitos colaterais graves. Um é que a pressão para difundir leva por exemplo a fraudes em ciência, com exposições que requerem desmentidos. Neste círculo de inadequações é imperioso comentar que uma Universidade paulista resolveu dar prêmios em dinheiro para seus membros que emplaquem inclusões nos periódicos científicos Nature e Science.

Precisamos de mais bom senso na aferição do valor de nossos profissionais na área médica - não pode ser só pelo currículo de trabalhos publicados.

\section{Vicente Amato Neto e Jacyr Pasternak}

*0s autores são médicos e professores universitários.

Recebido para publicação em 13/05/2008

Aceito em 25/78/2008 